\title{
Pemberdayaan Pemuda Dalam Pengembangan Atraksi Wisata Ikan Sakti Sungai Janiah Nagari Tabek Panjang
}

\author{
Syukri1 ${ }^{1}$ Elfi Tasrif ${ }^{2}$, Khairi Budayawan ${ }^{3}$, Yuliana ${ }^{4}$ \\ ${ }^{1234}$ Teknik Elektronika/ Universitas Negeri Padang \\ *)Corresponding author, $\equiv$ yuliana@fpp.unp.ac.id
}

(Di isioleh editor)

Revisi 11/12/2019;

Diterima 07/01/2020

Publish 01/02/2020

Kata kunci:

pemberdayaan, pemuda, pariwisata, Ikan Sakti Sungai Janiah

\begin{abstract}
Abstrak
Pemberdayaan pemuda dalam pariwisata merupakan sebuah langkah yang tepat untuk mencapai dampak positif kegiatan tersebut. Identifikasi dimensi utama dari pemberdayaan pemuda adalah, seperti: (1) lingkungan yang aman dan lebih ramah; (2) partisipasi aktif; (3) pembagian peran dalam masyarakat; dan (4) upaya mencapai perubahan. Upaya melakukan pengembangan pariwisata melalui pemberdayaan pemuda mulai dilakukan karena pemikiran jangka panjang kelompok dewasa untuk memperoleh hasil yang lebih optimal. Pemuda dianggap memiliki kemampuan yang lebih besar dalam melakukan pengembangan atraksi untuk menarik kedatangan wisatawan. Permasalahan adalah sejauh mana inisiatif pemuda di Nagari Tabek Panjang untuk mengembangkan atraksi wisata Ikan Sakti Sungai Janiah. Penelitian ini bertujuan untuk melakukan pemetaan terkait kebutuhan pemuda dalam melaksanakan pengembangan dan siapakah yang dibutuhkan untuk membantu terlaksananya kegiatan tersebut. Penelitian dilakukan dengan metode kualitatif untuk memperoleh data dari informan. Teknik pengumpulan data dilakukan dengan wawacara, data yang telah diperoleh kemudian dianalisis secara deskriptif dan disajikan sehingga lebih mudah dipahami oleh pembaca. Hasil penelitian menunjukkan bahwa pemuda memerlukan pemicu untuk menghasilkan inisiatif bagi atraksi wisata Ikan Sakti Sungai Janiah. Program pengabdian masyarakat dari Universitas Negeri Padang merupakan salah satu solusi untuk memberdayakan para pemuda.
\end{abstract}

This is an open access article distributed under the Creative Commons Attribution License, which permits unrestricted use, distribution, and reproduction in any medium, provided the original work is properly cited. (C2019 by author(s)

\section{PENDAHULUAN}

Pemberdayaan adalah sebuah proses aksi sosial dan individu untuk mendapatkan kontrol danpenguasaan, dalam rangka meningkatkan kesetaraan dan kualitas hidup 


\section{Suluah Bendang: Jurnal Ilmiah Pengabdian Kepada Masyarakat}

(Zimmerman, 2000). Pemberdayaan adalah proses aksi sosial yang dapat terjadi diberbagai level, seperti individu, keluarga, organisasi, dan komunitas. Secara umum, pemberdayaan merupakan upaya memberikan otoritas atau kekuatan kepada individu atau kelompok untuk mengaktualisasikan diri atau memberi pengaruh pada suatu kegiatan. Pemberdayaan pemuda dalam pariwisata merupakan upaya penting untuk mengoptimalkan hasil yang ingin dicapai (Aghazamani, 2017).

Pariwisata merupakan industri penting karena potensinya untuk menciptakan lapangan kerja, bisnis baru, dan pendapatan langsung bagi para pengelolanya.Pariwisata memberikan cara transformatif dalam memberdayakan pemuda dan menciptakan lapangan kerja bagi mereka. Permasalahan sosial, keterbatasan lapangan kerja, hal tersebut dapat diatasi melalui kehadiran pariwisata yang mampu menyerap potensi kaum muda. Pariwisata diakui sebagai salah satu sektor terkemuka di dunia selama 60 tahun terakhir, pariwisata terus tumbuh dan berkembang menjadi sektor ekonomi yang besar dan berkembang pesat di dunia (United Nations World Trade Organisation (UNWTO), 2015).

Pemuda secara khusus lebih banyak diserap di sektor pariwisata, hal ini terjadi karena tingginya permintaan karena tidak adanya syarat khusus untuk pekerja di sektor ini (Yunis, 2009). Upaya untuk memperoleh hasil yang maksimal dilakukan dengan memberikan pelatihan dasar yang mereka perlukan.Salah satu bentuk nyata dari pemberdayaan pemuda adalah menciptakan atraksi wisata pendukung yang menarik kedatangan wisatawan dan meningkatkan kepuasannya. Aktivitas pariwisata merupakan salah satu sektor pembangunan yang berkontribusi bagi pendapatan daerah. Pariwisata merupakan sebuah fenomena dan keterkaitan yang muncul karena interaksi wisatawan, bisnis penyedia jasa, pemerintah dan komunitas setempat, dalam proses mendatangkan wisatawan atau pengunjung (Wardiyanta, 2006). Pariwisata berkembang menjadi sektor yang memberikan efek nilai manfaat kepada banyak pihak dari pemerintah, masyarakat, ataupun swasta.

Partisipasi adalah keterlibatan individu atau kelompok masyarakat untuk mencapai suatu tujuan bersama Muslim, 2008). Bentuk partisipasi bermacam-macam, mulai dari partisipasi langsung dan tidak langsung. Partisipasi pemuda di Nagari Tabek Panjang tergolong sebagai partisipasi langsung, karena mereka melakukan pengembangan atraksi wisatanya dengan mempelajari atraksi wisata baru untuk menarik kunjungan wisatawan. Hal ini menunjukkan bahwa masyarakat di Nagari Tabek Panjang menginginkan perubahan yang berdampak pada peningkatan kesejahteraan. Wisatawan yang datang di Nagari Tabek Panjang pada umumnya tidak tertarik untuk berkunjung kembali, karena atraksi yang monoton. Upaya untuk meningkatkan kunjungan dapat dilakukan dengan menambah atraksi wisata tersebut.

\section{METODE PELAKSANAAN}

Metode yang digunakan adalah pengumpulan data kualitatif, proses dilakukan dengan melakukan observasi, wawancara, dan konfirmasi terkait data yang ditemukan di lapangan. Penelitian kualitatif menjadi pilihan tepat karena mampu menjawab pertanyaan penelitian secara lebih jelas dan sesuai dengan kondisi yang dialami oleh para pihak yang terlibat dalam kepariwisataan. Penelitian dilakukan di Nagari Tabek Panjang, Kecamatan Baso, Kabupaten Agam selama 3 bulan, dari bulan Juli - Oktober 2019. Subjek penelitian adalah tokoh-tokoh yang memiliki informasi terkait kegiatan pariwisatan, kelompok pemuda, dan kehidupan sosial masyarakat di Nagari Tabek Panjang. Tokoh tersebut antara lain: Wali Nagari, alim ulama, tokoh budaya, tokoh perempuan, pemuda, dan aktifis pariwisata. Objek penelitian dalam penelitian kualitatif pada umumnya terdiri dari tiga komponen, yaitu: tempat, pelaku, dan aktivitas (Sugiyono, 2014). Penelitian ini telah memiliki ketiga komponen tersebut, yaitu: objek wisata Ikan Sakti Sungai Janiah, kelompok pemuda, dan pemberdayaan kelompok pemuda. 


\section{HASIL DAN PEMBAHASAN}

Objek Ikan Sakti Sungai Janiah merupakan salah satu objek wisata yang ada di Nagari Tabek Panjang Kecamatan Baso Kabupaten Agam. Objek wisata ini memiliki potensi atraksi wisata alam, budaya maupun buatan yang dapat dikembangkan. Dalam pengembangan atraksi wisata dibutuhkan peran penting masyarakat, diantaranya dengan pemberdayaan pemuda di Objek Wisata Ikan Sakti Sungai Janiah. Untuk mendukung pengembangan atraksi wisata tersebut dibutuhkan fasilitas wisata sehingga dapat memberikan kenyamanan bagi wisatawan. Hal ini dilakukan untuk meningkatkan minat wisatawan berkunjung ke Objek Wisata Ikan Sakti Sungai Janiah.

Berdasarkan data yang didapatkan dari pengabdian kepada masyarakat tahun 2018, pengelolaan di lakukan oleh Kelompok Sadar Wisata (Pokdarwis) Ikan Sakti Sungai Janiah. Dalam hal ini Pokdarwis menyampaikan beberapa kendala dalam pengembangan objek wisata kedepannya seperti: Kurangnya minat pemuda untuk ikut serta dalam pengembangan atraksi wisata. Masih kurangnya pengetahuan pemuda dalam pengelolan atraksi wisata berupa sanggar seni dan kurangnya fasilitas atraksi wisata khususnya baju tari dan alat musik di Objek Wisata Ikan Sakti Sungai Janiah .

Keterbatasan atraksi wisata menghambat proses perkembangan perekonomian di objek wisata Ikan Sakti Sungai Janiah. Kerjasama antara Perguruan Tinggi dengan masyarakat merupakan solusi, khususnya terkait dengan inisiatifmemberdayakan pemuda dalam pengembangan atraksi wisata. Tujuannya adalah meningkatkan perekonomian masyarakat di lingkungan objek tersebut. Peran tim pengabdi dalam memfasilitasi masyarakat khususnya pemuda dari segi pengetahuan dan pengembangan atraksi wisata adalah upaya konkrit dan memberikan hasil yang terukur. Kegiatan pelatihan dan penyuluhan kepada pemuda untuk memeriahkan acara 17Agustusan dan pengangkatan penghulu, bantuan sarana atraksi berupa baju tari dan alat musik sebagai pendukung atraksi wisata, dan dukungan mengikuti festival tambua tansa merupakan hasil nyata pengabdian tim UNP.

Objek Wisata Ikan Sakti Sungai Janiah terletak di Kecamatan Baso Kanagarian Tabek Panjang. Secara geografis Nagari Tabek Panjang berada diantara $0^{\circ}-30$ LS, $100.28^{\circ}$ BT, dengan luas 19,19 KM2 berada pada ketinggian 800 - $900 \mathrm{~m}$ dpl.

Tabel 1. Batas Administratif Nagari Tabek Panjang

\begin{tabular}{cc}
\hline Sebelah Utara & Nagari Koto Baru, Salo dan Simarasok \\
\hline Sebelah Selatan & Nagari Koto Tinggi \\
Sebelah Timur & Nagari Padang Tarok \\
Sebelah Barat & Kecamatan Ampek Angkek dan Canduang \\
\hline Sumber: Profil Nagari Tabek Panjang, 2019
\end{tabular}

Nagari Tabek Panjang terdiri dari 4 Jorong. Yaitu : Jorong Baso, Jorong Tabek Panjang, Jorong Sungai Cubadak, dan Jorong Sungai Janiah. Dilihat dari potensi masing-masing Jorong di Nagari Tabek Panjang bepeluang untuk dikembangkan sebagai daerah transit, pariwisata, perdagangan dan pertanian. Hal ini dikarenakan posisi strategisnya sebagai kawasan Hitterland Agropolitan Kab. Agam dan Lintas segi tiga Payakumbuh, Batusangkar dan Bukittinggi. 


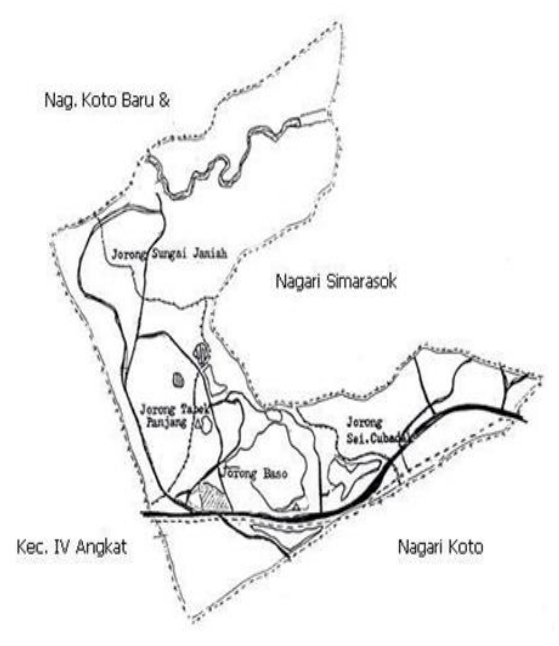

Gambar 1. Peta Nagari Tabek Panjang

Nagari Tabek Panjang memiliki beberapa objek wisata yang sudah mulai dikenal oleh wisatawan salah satunya adalah objek wisata Ikan Sakti Sungai Janiah. Objek wisata tersebut merupakan objek wisata alam berupa kolam berisikan ikan yang dilindungi oleh masyarakat. Berdasarkan legendanya ikan tersebut diyakini oleh warga sekitar berasal dari sepasang manusia. Disamping kolam Ikan Sakti Sungai Janiah juga terdapat sebuah bukit yang tingginya mencapai \pm 800 meter dari permukaan laut bernama Bukit Batanjua yang memiliki keanekaragaman flora dan fauna serta pemandangan alam yang sangat indah. Selain itu Bukit Batanjua memiliki keunikan tersendiri yaitu adanya mata air dalam sebuah batu yang dapat diminum dan tidak pernah kering meskipun dimusim kemarau. Berdasarkan kepercayaan dari warga sekitar meyakini air tersebut bisa menjadi obat untuk berbagai macam penyakit (Pengelola Objek Wisata).

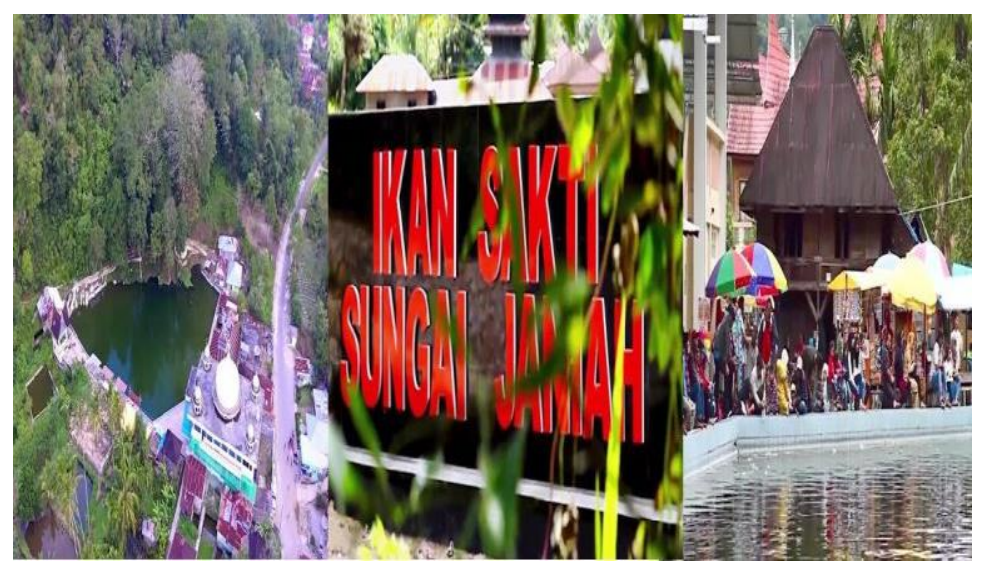

Gambar 2. Objek Wisata Kolam Ikan Sakti Sungai Janiah .

Objek wisata Ikan Sakti Sungai Janiah berpotensi untuk dilakukan pengembangan menjadi objek wisata unggulan di Kabupaten Agam. Hal ini didukung dengan perbukitan yang masih alami yang berpotesi untuk dijadikan wisata tracking, dimana wisatawan dapat menikmati pemandangan yang indah dari atas bukit tersebut. Selain itu pohon besar yang 
terdapat di sekitar objek wisata berpotensi dijadikan tempat atraksi wisata lainnya seperti flying fox. Kemudian debit air yang banyak serta adanya area kosong disekitar objek wisata bisa dijadikan arena memancing, sehingga dapat menjadi daya tarik tersendiri bagi wisatawan untuk berkunjung ke Objek Wisata Ikan Sakti Sungai Janiah. Tidak hanya itu sejarah dan legenda yang melekat di Objek Wisata Ikan Sakti SungaiJaniah menjadi daya tarik sendiri dalam pengembangan objek wisata tersebut, terutama untuk wisatawan yang menyukai sejarahsejarah objek wisata.Berikut gambar Objek Wisata Ikan Sakti Sungai Janiah.

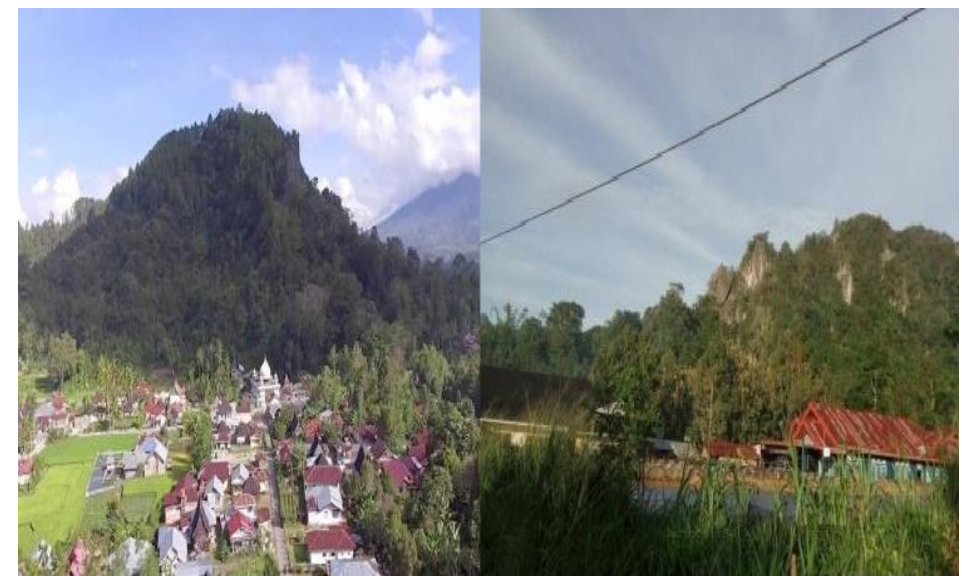

Gambar 3. Bukit Batanjua Objek Wisata Ikan Sakti Sungai Janiah

Berdasarkan gambar di atas terlihat keindahan alam Objek Wisata Ikan Sakti Sungai Janiah, dimana bangunan sekitar objek wisata yang masih terjaga keasliannya sehingga memberikan suasana asli Minangkabau. Selain itu pemandangan Bukit Batanjua dan pepohanan rindang memberikan nuansa alam yang sangat menarik dan memiliki potensi untuk dikembangkan berbagai kegiatan pariwisata di Objek Wisata Ikan Sakti Sungai Janiah.

Pemuda Nagari Tabek Panjang berhasil diberdayakan untuk mendukung kegiatan pariwisata, kegiatan rutin yang dilakukan adalah berlatih tari bagi kelompok pemuda putri, dan kelompok tambua tasa untuk pemuda laki-laki. Mereka mulai aktif berlatif dan tampil pada beberapa acara di tingkat Nagari dan Kabupaten. Tarian dan permainan musik para pemuda yang awalnya ditujukan sebagai atraksi wisata tambahan selain atraksi utama Ikan Sakti, ternyata mampu dimanfaatkan lebih lanjut sebagai sumber daya ekonomi.

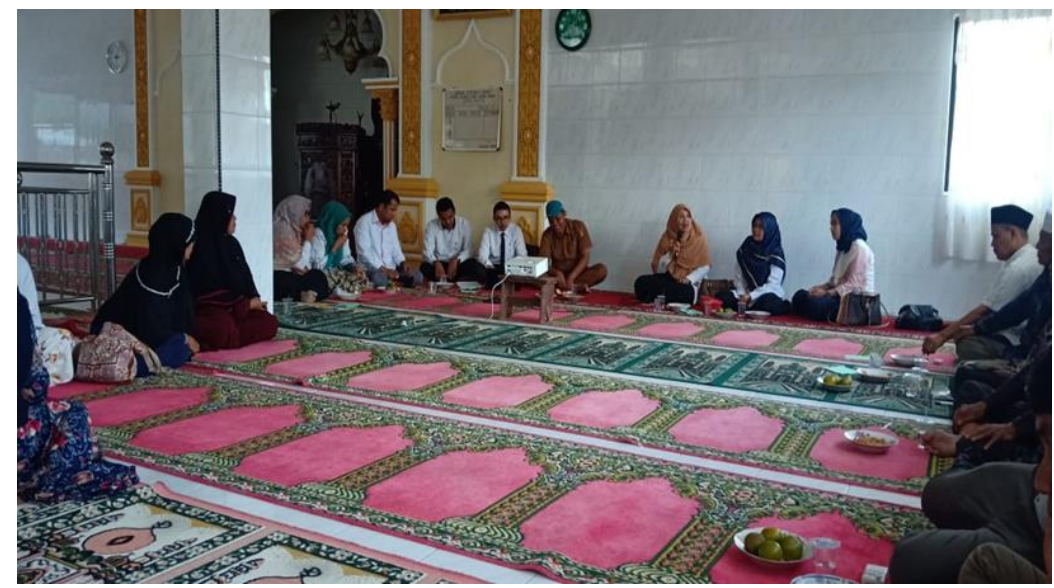

Gambar 4. Kegiatan diskusi bersama pemuda Nagari Tabek Panjang

Pemberdayaan Pemuda Dalam Pengembangan Atraksi Wisata Ikan Sakti Sungai Janiah Nagari Tabek Panjang | 107 Available online: http://sulben.ppj.unp.ac.id 


\section{Suluah Bendang: Jurnal IImiah Pengabdian Kepada Masyarakat}

Kegiatan yang dilakukan tim pengabdi bertemu dengan kelompok sasaran dihadiri oleh pengabdi dengan tim pengabdi lainnya dengan Wali Nagari Tabek Panjang, Kelompok Sadar Wisata Sungai Janiah, ketua pemuda yang tergabung dalam sanggar seni ikan sakti. Pada pertemuan tersebut Wali Nagari membuka kegiatan dan dilanjutkan diskusi dengan kelompok sasaran tentang program yang akan dilaksanakan. Kelompok sasaran sangat mengharapkan adanya pelatihan dan bantuan berupa sarana atraksi wisata sanggar seni berupa perlengkapan baju tari dan alat musik pendukung.Pelatihan Manajemen Kelompok berguna bagi kelompok sasaran supaya kelompok bisa mengatur kegiatan sanggar dengan baik yang pada akhirnya diharapkan dapat meningkatkan perekonomian anggota kelompok. Berbekal keterampilan seni yang dimiliki oleh kelompok sasaran dan tidak adanya sanggar seni di wilayah tersebut, sangat memberikan peluang bagi kelompok sasaran dapat kesemptan mengembangkan diri dan sekaligus dapat meningkatkan ekonomi dengan banyaknya atraksi seni yang dilakukan, seperti diundang tampil dalam acara pengangkatan penghulu, resepsi pernikahan dalan lain-lain.

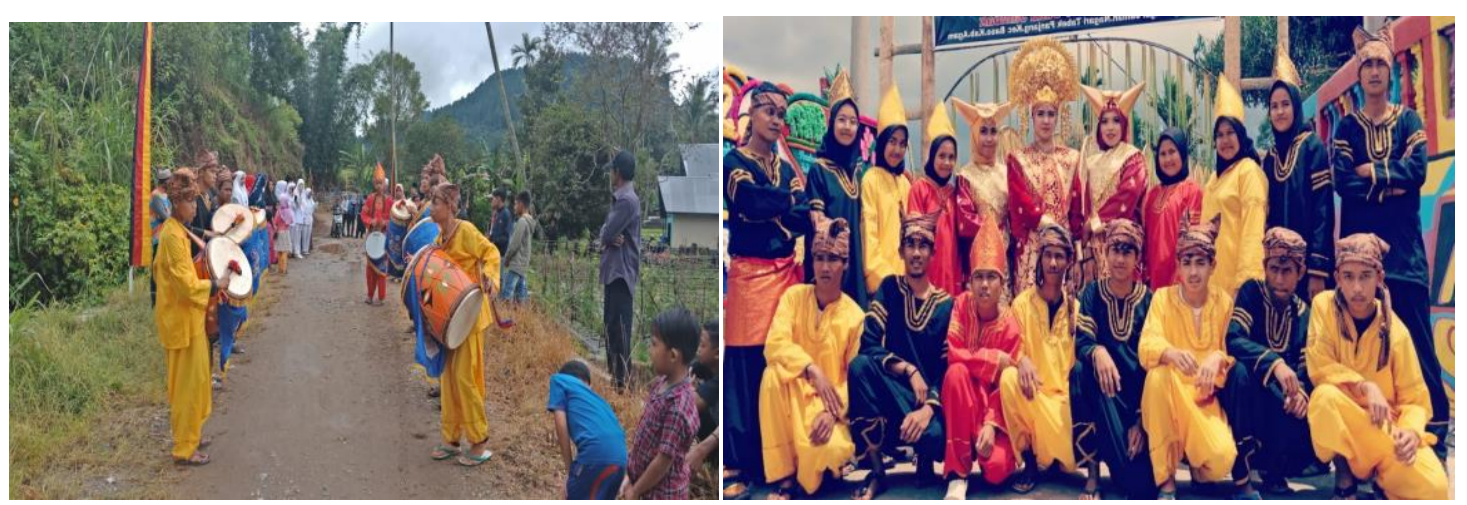

Gambar 5. Kegiatan diskusi bersama pemuda Nagari Tabek Panjang

\section{KESIMPULAN}

Pemberdayaan kelompok pemuda untuk kepariwisataan di Nagari Tabek Panjang telah berhasil dilaksanakan oleh tim pengabdi UNP dalam bentuk pelatihan dan pemenuhan kebutuan sarana pendukungnya. Kelompok pemuda yang sebelumnya tidak terlibat langsung dalam kegiatan pariwisata perlahan memperoleh posisi yang lebih baik dengan kemampuan tari dan permaian alat musiknya. Seiring dengan peningkatan jumlah wisatawan, maka kebutuhan untuk atraksi wisata tambahan perlu diupayakan oleh pengelola.

\section{DAFTAR PUSTAKA}

Aghazamani, Zeganeh. (2017). Empowerment In Tourism: A Review Of Peer-Reviewed Literature. Tourism Review International, 21, 333-346.

Fifth UNWTO International Conference on Tourism Statistics. Tourism: an engine for employment creation.

http://statistics.unwto.org/sites/all/files/pdf/yunis_text.pdf

Muslim, Aziz. (2008). Metodologi Pengembangan Masyarakat. Yogyakarta: UIN Sunan Kalijaga Press.

Sugiyono. (2014). Memahami Penelitian Kualitatif. Bandung: Alfabeta. 
United Nations World Trade Organisation. (2015). UNWTO Tourism Highlights, 2015 Edition. Madrid:UNWTO.

Yunis, E. (2009). Tourism and Employment: An overview by the UNWTO. Paper presented at

Zimmerman, M. A. (2000). Empowerment theory: Psychological, organizational, andcommunity levels of analysis. In J. R. E. Seidmann (Ed.), Handbook of communitypsychology. New York: Kluwer Academic/Plenum 